\title{
Managerial Overconfidence and Share Repurchases
}

\author{
PeI-Gi Shu ${ }^{\dagger}$, Yin-HuA YeH ${ }^{\ddagger}$, Tsui-Lin Chiang ${ }^{\S}$ AND JUI-Yi HunG ${ }^{\dagger}$ \\ 'Department of Business Administration, Fu Jen Catholic University, \\ New Taipei City, Taiwan \\ ${ }^{\ddagger}$ Graduate Institute of Finance, National Chiao Tung University, Hsinchu, \\ Taiwan and \\ ${ }^{\S}$ Graduate Institute of Business Administration, Fu Jen Catholic University, \\ New Taipei City, Taiwan
}

\begin{abstract}
Following prior studies, we use keywords in press portrayals to gauge managerial overconfidence. We hypothesize that managerial overconfidence is related to a manager's perception that the firm is undervalued. Results from 2744 share repurchase programs launched by 783 listed firms in Taiwan confirm this hypothesis. We find that managerial overconfidence is positively correlated with the intensity of share repurchasing, which is measured by scale, execution, frequency, and the difference between the announced price and post-execution price. Moreover, the programs launched by overconfident managers were not undervalued and therefore were associated with reduced post-announcement returns.
\end{abstract}

\section{INTRODUCTION}

Many CEOs never stop believing their stock is cheap. In other instances, a less benign conclusion seems warranted ... Continuing shareholders are hurt unless shares are purchased below intrinsic value (Buffett 2012).

Over the past few decades, share repurchase programs have been deemed an alternative method of disbursing cash to shareholders and have become an important payout method for US firms. ${ }^{1}$ Some recent large-scale share repurchases have even been noted by the market. ${ }^{2}$ This movement went global in the 1990 s,

1 The share repurchase programs were very large. For example, in 1998, the dollar amount of announced repurchases in the US market exceeded cash dividends for the first time (Grullon and Michaely 2002). The dollar amount over the 2004-2008 period rose to $\$ 1.9$ trillion, triple the amount in the prior 5 years. All in all, S\&P 500 companies reduced the index's market capitalization by $17 \%$ through share repurchases. Recently, S\&P Indices announced that stock buybacks increased for the ninth consecutive quarter, reaching $\$ 118.4$ billion for the third quarter of 2011.

2 In September 2010, Warren E. Buffett announced that Berkshire would repurchase its shares at a price of up to $110 \%$ of book value. On March 3, 2011, Ahold announced a buyback of $€ 1$

(c) 2012 The Authors. International Review of Finance (C) International Review of Finance Ltd. 2012. Published by Wiley Publishing Asia Pty Ltd 


\section{International Review of Finance}

as countries such as Canada and the UK also increased their repurchases. Other countries, such as Germany, Taiwan, Hong Kong, and Japan, which formerly had prohibited share repurchases, adopted provisions allowing resident firms for the first time to repurchase equity in the open market. In Taiwan, firms were permitted to implement share repurchase programs starting in August 2000. Between August 2000 and June 2005, more than half the firms listed on the Taiwan Stock Exchange announced open-market share repurchases, and NTD 247 billion (equivalent to USD 8.23 billion) worth of stock was bought back (Yu 2011).

Do share repurchase programs add value to continuing shareholders if they are used to signal undervaluation of the current share price (e.g., Asquith and Mullins 1986; Comment and Jarrell 1991; Dann et al. 1991; Hertzel and Jain 1991; Lee et al. 1992; Ikenberry et al. 1995)? Some recent cases indicate that the undervaluation argument might be invalid. For example, HTC, the largest smartphone manufacturer in Taiwan, had launched a large-scale share repurchase program with an average buyback price of NTD 850.9 on August 17, 2011. However, the close price on December 9, 2011 was a mere NTD 405.5. The total loss from the repurchase program (NTD 8 billion or USD 266 million) was almost equivalent to HTC's total capitalization (NTD 8.6 billion). We surmise that share repurchase programs add value if and only the current shares are indeed undervalued and the signal of undervaluation is accepted as such by the market.

Why would managers believe their firms are undervalued when the undervaluation signal is not approved by the market? In this paper, we relate managerial overconfidence (MOC) to share repurchase programs. Overconfidence is an obvious fact of human nature. It means that individuals are inclined to overstate their acumen relative to the average (Larwood and Whittaker 1977; Svenson 1981; Alicke et al. 1985). This inclination is further reinforced by self-serving biases to attribute good outcomes to one's own actions and bad outcomes to bad luck (Miller and Ross 1975). Roll (1986) was the first to relate overconfidence to managerial actions, arguing that overconfident managers tend to overbid acquired targets. Heaton (2002) elaborated on this effect of overconfidence on managerial actions. The impact of MOC has been examined empirically in several corporate scenarios. ${ }^{3}$

billion with an expected duration of 18 months. IBM's huge buyback plan of April 2011 was expected to be worth $\$ 50$ billion until 2015. Finally, Apple's board authorized a $\$ 10$ billion share repurchase program to begin in the quarter starting September 30, 2012.

3 For example, Malmendier and Tate (2005a) indicated that managerial overconfidence heightens the sensitivity of corporate investments to cash flow, especially for equity-dependent firms. Malmendier and Tate (2008) found that chief executive officer (CEO) overconfidence was associated with acquisitiveness. Ben-David et al. (2007) documented that firms with overconfident chief financial officers made more investments, were more sensitive to the investment-cash relation, and had a lower cash dividend payout and higher long-term leverage. Hribar and Yang (2010) found that overconfident managers were more likely to issue optimistically biased forecasts. Schrand and Zechman (2012) found that overconfidence was positively associated with the likelihood of earnings management and financial fraud. Malmendier et al. (2010) found that overconfident managers were less likely to use external finance and issued less equity than other managers. 


\section{Managerial Overconfidence and Share Repurchase}

Overconfident managers tend to believe that their firms are undervalued. Undervaluation is one of the most widely cited reasons that firms launch share repurchases. However, to our surprise, there is little empirical evidence directly relating MOC to share repurchases. Our inference is intuitive: overconfident managers holding optimistic (unrealistic) beliefs about future performance tend to perceive that their firm's stock is undervalued; therefore, they launch share repurchase programs to raise the share price.

In evaluating 2744 repurchase programs launched by 783 listed Taiwanese firms in 2000-2008, we first follow prior studies ${ }^{4}$ and use keywords from press portrayals to gauge MOC. Exploiting these keywords, Malmendier and Tate (2005b) proposed a simplified overconfidence measure that relies on the perceptions of outsiders rather than the actions of CEOs. Their measure is a good fit for our study because the target of our investigation is market response. ${ }^{5}$

We then investigate the relation between MOC and the intensity of share repurchase programs. Intensity can be defined by scale (the percentage of shares or dollars repurchased), execution rate, frequency, and price difference (the difference between the middle of the announced price range and the average post-execution price). We find significant positive relationships between MOC and scale, execution rate, and price difference. These positive relations remain significant after controlling other motive variables ${ }^{6}$ and the possible effects of endogeneity.

Next, we examine whether the share repurchase programs launched by overconfident managers were undervalued. Our results show that firms with high market-to-book equity had managers with a high degree of overconfidence. Firms in which share repurchase programs were launched by overconfident managers were not in fact undervalued. Does this mean that markets factor MOC into their responses to share repurchase programs? We find that MOC is negatively and significantly correlated with cumulative abnormal returns from

4 Example are Malmendier and Tate (2005a, 2008), Brown and Sarma (2007), Hribar and Yang (2010), and Ben-David et al. (2007).

5 Alternatively, Malmendier and Tate (2005a) discuss the use of habitual increases in a CEO's holding of company stock as a proxy for managerial overconfidence. Because in Taiwan, executive options have been widely used only by high-tech firms, and a large proportion of the granted options have not yet reached maturity, we investigate only changes in managerial shareholding. We consider managers to be overconfident when the increase in their shareholdings exceeds the proportion of bonus shares granted to employees. This increase in their holdings is voluntary. The results using the alternative measure are less significant than with the original method, except for managerial overconfidence being positively correlated with execution rate.

6 What motivates firms to engage in repurchasing shares has been extensively discussed in the literature. The first paper, which addresses agency concerns, argues that a share repurchasing program is really a distribution of excess cash flow (Jensen 1986). This argument is supported by the finding of a positive relation between repurchases and cash flow (Stephens and Weisbach 1998). The topic of the second paper is the signaling of undervaluation (Vermaelen 1981). The next two papers, which address leverage adjustment, argue that stock repurchasing can be used to increase a firm's leverage ratio (Bagwell and Shoven 1989; Opler and Titman 1996). The final paper describes how to fend off unwanted takeover attempts (Bagwell 1991). 


\section{International Review of Finance}

the announcement day up to 2 months [CAR $(0,40)]$ or 3 months [CAR $(0,60)$ ] after the announcement. This result implies that the market gradually came to realize that the buyback programs launched by overconfident managers were not undervalued, and they therefore attached a lower valuation to them as time passed.

The potential contributions of this study are multifold. First, we explore share repurchase programs from the perspective of behavioral finance, and we find a positive relationship between these two constructs. The results support the postulation of Ben-David et al. (2007) that overconfident firms are less likely to pay dividends and more likely to repurchase shares than are other firms. In an effort to advance our understanding of how managerial inclinations affect corporate policies, we further explore the relation between the extent of MOC and the intensity of share repurchase programs. Second, we advance the pressbased measurement of overconfidence by tracing the keywords for MOC back to the hiring of the incumbent manager. By so doing, we are able to ensure that the measure tracks the behavior of the incumbent manager rather than that of the launching firm as a whole during the manger's tenure. Third, we document the rational conclusion of the market, namely, that investors gradually come to realize that share repurchase programs launched by overconfident managers are not undervalued, and therefore, they assign them a lower value than they would otherwise.

The rest of this paper is organized as follow. In section 2, we review the relevant literature. In section 3, we describe our data sources, variables, and empirical models. In section 4 , we report the empirical results. In section 5, we describe the robustness of these results. In section 6 , we summarize our conclusions.

\section{LITERATURE AND HYPOTHESES}

We begin this section by briefly reviewing share repurchase programs in Taiwan, followed by a literature review and development of our hypotheses.

\section{A. Share repurchase programs in Taiwan}

Taiwan imposes stricter guidelines than other countries on the declaration of repurchase purposes, disclosure transparency, and repurchase execution. Article 28-2 of the Securities and Exchange Law stipulates that firms preparing to launch a repurchase program must file their purposes in accordance with at least one of the following principles: (1) preparation for employees' bonus shares; (2) reservation for the execution of derivatives such as warrants and convertibles; and (3) protection of shareholders' rights with the repurchased shares to be written off against owners' equity. The buyback announcement must be made publicly within 2 days after board approval. In the meantime, the repurchasing firm must disclose the price range of the repurchase. The ceiling price must be 
$150 \%$ of the 30-day average price or the 10-day average price (whichever is higher) prior to the date of board approval. The floor price must be $70 \%$ of the close price at the date of board approval. The maximum amount of a share repurchase program must be no more than $10 \%$ of the total shares issued, and no more than the sum of the retained earnings and the capital surplus. In general, open-market repurchases start 2-3 days after the public announcement, which is $4-5$ days after board approval. The program must be finalized in 2 months and the exact execution must be reported to the Financial Supervisory Commission within 5 days after the program expires. If the firm expects to extend the execution of the share repurchase program beyond the 2-month limit, another board approval is needed.

Share repurchase programs are more strictly regulated in Taiwan than in the United States. First of all, in the United States, market there is neither a reporting requirement for repurchasing nor a predefined expiration period, which makes it difficult to gauge the impact of repurchasing activity. In contrast, the open-market buyback policy in Taiwan stipulates an execution period of no more than 2 calendar months. Moreover, any large repurchase (more than NTD 300 million or $2 \%$ of the outstanding shares) must be disclosed to the market within 2 days of the repurchase.

As of December 2008, the number of listed firms engaging in share repurchase programs in Taiwan had rapidly risen to 783. These firms implemented a total of 2744 repurchase programs. Many of the firms were repeat players; some launched more than 15 such programs during our sample period. Share repurchase programs being pervasively recognized signals of undervalution are welcome by the listed companies as well as the government.

\section{B. Managerial overconfidence}

Overconfidence is conceptualized in different ways in the psychology literature. One is the 'better-than-average' effect, the tendency of individuals to think of themselves as 'above average' on positive characteristics (e.g., Svenson 1981; Alicke et al. 1985, 1995; Kruger 1999). The effect, which has been extensively examined (e.g., Cooper et al. 1988), is further reinforced by evidence on attribution bias, the self-serving inclination to attribute good outcomes to one's actions and bad outcomes to luck (Feather and Simon 1971; Miller and Ross 1975).

Overconfident is a particularly appropriate label for many top managers for several reasons. First, skilled individuals lacking an obvious comparison group tend to be overconfident (Camerer and Lovallo 1999; Kruger 1999). Second, overconfidence is most often found when outcomes are defined abstractly (Nisbett and Ross 1980; Moore and Kim 2003). Third, people are most optimistic about outcomes, which they believe are under their own control (Langer 1975) or to which they are highly committed (Weinstein 1980). These three principles characterize top managers so well that they continually overestimate 
their own skills and are therefore too optimistic about the outcomes of their decisions.

The overconfidence hypothesis is similar to the 'hubris' hypothesis proposed by Roll (1986). It is also relevant to the contentions of Heaton (2002) and of Landier and Thesmar (2009) that managers overestimate the probability of a project's success. In corporate finance, this form of overconfidence has been applied in several contexts: contracts with managers (Gervais et al. 2003), succession tournaments (Goel and Thakor 2008), dividend policy (Deshmukh et al. 2010), mergers (Malmendier and Tate 2008), and investment-cash sensitivity (Malmendier and Tate 2005a).

The biggest challenge for empirical researchers is to construct a plausible measure of overconfidence. Malmendier and Tate (2005a) use CEOs' personal portfolio transactions to signal their beliefs about a firm's future performance. This 'revealed beliefs' approach requires detailed information about CEOs' personal portfolio transactions involving their company's stock and options. Because CEOs invest so much human capital in their companies, they must diversify their portfolios even if they are only modestly risk averse. CEOs who do not favor diversification, such as those who hold a relatively large amount of their company's stock, are reluctant to exercise deep-in-the-money options, or they hold back on exercising these options until the final year of the contract. This latter kind of CEO is considered to be overconfident.

A second approach to assessing overconfidence is to use a 'press-based' measure, which captures how outsiders perceive the CEO. This measure was our choice for the present study. Specifically, the number of positive words is compared to the number of neutral or negative words, as defined in Malmendier and Tate (2008). We measure the overconfidence of the incumbent managers so that we can capture its development over time.

\section{MOC and share repurchases}

Overconfident managers tend to overestimate their firm's future cash flow or underestimate the volatility of that cash flow. As a result, they tend to believe that the market undervalues their firm. They therefore launch share repurchase programs to raise the current price level. An extension of this argument is that overconfident managers, who believe that their firm is undervalued, tend to overinvest in projects such as value-detrimental mergers (Malmendier and Tate 2008), prefer internal sources of financing (Malmendier and Tate 2005a), and be relatively unlikely to pay dividends (Deshmukh et al. 2010).

In our study, we take a close look at how the level of overconfidence affects the intensity of share repurchase programs. We define the level of MOC as the ratio of positive words (expressing overconfidence) to neutral and negative words. Thus, MOC is a continuous variable. We define the intensity of the share repurchase program in four ways: scale (the percentage of total shares or dollars repurchased), execution rate, number of repurchases, and 
price difference. ${ }^{7}$ The higher the level of MOC, the larger the anticipated price difference that must established, and the more intensive the launched programs must be. We therefore propose the following hypothesis:

Hypothesis 1: The level of MOC is positively correlated with the intensity of share repurchase programs.

A second important issue is how investors respond to the share repurchases of overconfident managers. Deshmukh et al. (2010) found that the magnitude of the positive market reaction to a dividend increase announcement was lower for firms managed by overconfident CEOs than for firms managed by nonoverconfident CEOs. This result implies that investors are skeptical about a signal they perceive as affected by MOC as well as by its content. Thus, the positive outcome of the share repurchase is at least partially offset by the negative impact of MOC. In the extreme case, MOC dominates the equation. Therefore, we propose the following hypothesis:

Hypothesis 2: The market responds negatively to share repurchase programs launched by overconfident managers.

We also address control variables that were noted in prior studies of share repurchases. First, we expect excess cash or cash flow to be positively correlated with the buyback programs (Easterbrook 1984; Jensen 1986). Second, book-tomarket equity, a commonly used surrogatefor undervaluation (e.g., Dann 1981; Asquith and Mullins 1986; Comment and Jarrell 1991; Hertzel and Jain 1991; Lee et al. 1992), is thought to be positively correlated with buyback programs. Third, according to the optimal leverage hypothesis, share repurchases are employed to adjust the capital structure when the current debt ratio is below the target capital structure (Bagwell and Shoven 1989; Opler and Titman 1996). To test this hypothesis, we use debt deviation, which we define as the difference between the current debt ratio and the target debt ratio of Hovakimain et al. (2004). Fourth, the management incentive hypothesis indicates that managers who hold a large number of stock options are particularly interested in maintaining the share price, a goal they can accomplish by repurchasing the shares. There is evidence that firms that compensate their executives with a large number of stock options find it beneficial to repurchase stock (Dunsby 1994; Jolls 1996; Fenn and Liang 1997). The variable we use to test this hypothesis is executive stock options. Fifth, according to the takeover deterrence hypothesis, a repurchase can be used as a takeover defense because it can increase the lowest

7 The price difference can also be defined as the difference between the close price on the day of board approval and the middle of the announced price range. Unfortunately, the price range is preset with a cap of $150 \%$ of the reference price (the 10-day or 30-day average prior to the announcement day, whichever is higher) and a floor of $70 \%$ of the close price on the announcement day. This alternative price difference is less meaningful than the one we choose and thus we do not consider it further. In this study, we define the price difference as the difference between the middle of the price range and the 3-day average price after program execution. We use the price difference to represent program intensity on the one hand and to capture market response on the other. 
price at which the stock is available (Bagwell 1991). The variable we use to this hypothesis is takeover threat. All the aforementioned variables are included in our models, which assess the relation between MOC and the intensity of share repurchase programs.

\section{DATA AND VARIABLES}

Data on share repurchases by Taiwanse firms from August 2000 through December 2008 were collected from the Taiwan Economic Journal (TEJ). Share repurchasing programs ${ }^{8}$ were not allowed for listed Taiwanese companies until August 2000. After exclusion of financial firms that are subject to different regulations, our final sample consists of 2744 share repurchases launched by 783 listed firms. Table 1 summarizes the sample characteristics by industry (panel A), number of repurchases per firm (panel B), and year (panel C). The results show that most of the firms deal in electronic appliances $(379,13.81 \%)$, followed by computers and computer peripherals $(354,12.9 \%)$ and semiconductors $(322,11.73 \%)$. Around $30 \%$ of the firms (233) launched only one share repurchase program during the sample period. However, $19 \%$ of the firms launched more than five programs during this period. The most extreme case is 36 programs in 8 years. This pervasive and repeated share repurchasing suggests something is going on beyond a signaling of undervaluation because the market is unlikely to undervalue shares all the time across all firms. The industry breakdown in panel A illustrates that share repurchase programs are more common among high-tech firms than traditional manufacturing firms. For example, there are only two repurchase programs in the glass and ceramics industry.

Following Malmendier and Tate (2005a) and Brown and Sarma (2007), we use press portrayals to gauge MOC. Data from January 1996 and October 2009 were taken from the 'News Clip' file of the TEJ. This file, which was not available until January 1996, is a compilation of all press reports specific to a given company. An advantage of this measure is that it captures the perception of outsiders. Thus, any strategic moves by the manager are reflected in the market price, which is responsive not only to the action itself but also to the manager's behavioral inclination.

We define press-based MOC as follows: ${ }^{9}$

8 Because the rules in Taiwan strictly stipulate that firms must file the purpose of their share repurchases, make a public announcement within 2 days after board approval, disclose the price range of the repurchases, and finalize the repurchases in the open market within 2 months, the repurchases are carefully monitored by investors from the announcement to the end of the repurchase. We therefore define it as a share repurchase program.

9 We also define managerial overconfidence as $a / b, a /(a+b)$ (with $a / b$ subject to managerial changeover) as a dummy coded 1 if $a>b$ and 0 otherwise, and as a dummy subject to managerial changeover, assigning 1 if $a>b$ and 0 otherwise. The results from yet other definitions of managerial overconfidence are qualitatively similar and are not described here for brevity. 
Table 1 Sample distribution

\begin{tabular}{lrrlrr}
\hline Panel A: by industry & \multicolumn{6}{c}{ Industry } & No. & $\%$ \\
\hline Industry & \multicolumn{1}{c}{ No. } & \multicolumn{1}{c}{$\%$} & \multicolumn{1}{c}{$\%$} \\
\hline Electronic appliances & 379 & 13.81 & Trade and merchandise & 54 & 1.97 \\
Computers and peripherals & 354 & 12.90 & Electric appliances and cable & 53 & 1.93 \\
Semiconductors & 322 & 11.73 & Plastics & 49 & 1.79 \\
Optical electronics & 233 & 8.49 & Biomedical & 35 & 1.28 \\
Other electronics & 179 & 6.52 & Transportation & 34 & 1.24 \\
Telecommunication & 160 & 5.83 & Food & 28 & 1.02 \\
Information services & 119 & 4.34 & Managed stocks (Gui-Tai) & 27 & 0.98 \\
Electronic channels & 112 & 4.08 & Paper & 26 & 0.95 \\
Electronic mechanics & 107 & 3.90 & Cement & 23 & 0.84 \\
Textiles and fibers & 101 & 3.68 & Rubber & 16 & 0.58 \\
Construction & 92 & 3.35 & Gas and fuels & 16 & 0.58 \\
Other & 78 & 2.84 & Truisms & 9 & 0.40 \\
Iron & 66 & 2.41 & Automobiles & 2 & 0.07 \\
Chemistry & 59 & 2.15 & Glass and ceramics & 2744 & 100.00 \\
Total & & & & &
\end{tabular}

Panel B: by frequency

\begin{tabular}{lcclrr}
\hline No. of reps. & Firms & $\%$ & No. of reps. & Firms & \multicolumn{1}{c}{$\%$} \\
\hline 1 & 233 & 29.78 & 4 & 66 & 8.43 \\
2 & 154 & 19.67 & 5 & 54 & 6.90 \\
3 & 130 & 16.60 & 6 and above & 146 & 18.65 \\
Total & & & & 783 & 100.00 \\
\hline
\end{tabular}

Panel C: by year

\begin{tabular}{llrrrr}
\hline Year & No. & $\%$ & Year & No. & \multicolumn{1}{c}{$\%$} \\
\hline 2000 & 217 & 7.91 & 2005 & 285 & 10.39 \\
2001 & 213 & 7.76 & 2006 & 231 & 8.42 \\
2002 & 173 & 6.30 & 2007 & 217 & 7.91 \\
2003 & 191 & 6.96 & 2008 & 783 & 28.54 \\
2004 & 434 & 15.82 & & & 100.00 \\
Total & & & & 2744 & \\
\hline
\end{tabular}

This table reports the sample distribution of share repurchases from August 2000 through December 2008. Panel A reports the repurchases by industry. Panel B reports how frequently firms engaged in share repurchase programs. Panel $\mathrm{C}$ reports the distribution of repurchases by year.

$$
\text { MOC }: a /(a+b) \text { subject to managerial changeover }
$$

We use different elements of the CEO's portfolio as proxies for MOC, where $a$ is the number of times the words 'confident' or 'optimistic' are used, and $b$ is the number of times the terms 'not confident', 'not optimistic', 'reliable', 'cautious', 'practical', 'frugal' and 'steady' are used. The measures are cumulated up to the year's end but prior to the share repurchase announcement; thus, the overconfidence measures for each firm or each manager differ as a function of time. This 
approach ameliorates the concern of possible autocorrelation for overconfidence measures. Moreover, the measure reflects managerial changes, meaning that the trace of keywords it up to the beginning when the incumbent manager was hired. Thus, we are able to address the trajectory or development of the MOC.

Table 2 shows that the average degree of overconfidence is 0.46 and the average number of share repurchase programs per firm is 3.74 . The average number of shares repurchased is 7.76 million, which is equivalent to $2.03 \%$ of the total outstanding shares. The average dollar amount of each repurchase is NTD 162.71 million, or $1.63 \%$ of the total equity value. On average, the announced programs were executed $70 \%$ of the time. The median execution rate is $85 \%$.

We define the price difference as the difference between the median price within announced price range, which is the average price 3 days before the program divided by the average price 3 days after the program.

$$
\text { Price Difference }=\left(\left(M P-P_{+3}\right) / P_{+3}\right)
$$

This measure gives the price decline following the share repurchase program. If the program was motived by MOC, we would expect to find the price difference to be positively correlated with the level of MOC. The average price difference is $17.8 \%$.

Statistics for the control variables are also reported in Table 2 . The average book-to-market equity, which indicates the probability that the firm is undervalued, is 0.92. The average free cash flow and cash level are 0.04 and 0.15 , respectively; these are surrogates for the excess capital that firms can distribute excess cash through the share repurchase.

Debt deviation is defined as the difference between the current debt level and the optimal debt level. It is estimated by the following regression:

$$
\begin{aligned}
\operatorname{Debt}^{*}{ }_{i t}= & \beta_{0}+\beta_{1} M B_{i, t}+\beta_{2} S R T_{i(t-1)}+\beta_{3} R O A_{i t}+\beta_{4} N O L C_{i t}+\beta_{5} S_{i z e_{i t}} \\
& +\beta_{6} \operatorname{TanA}_{i t}+\beta_{7} S E_{i t}+\beta_{8} R D E_{i t}+\beta_{9} I L_{i t}+\varepsilon_{i t}
\end{aligned}
$$

where Debt* is the optimal debt level, $M B$ is the market-to-book equity at year's end, $S R T$ is the annual return, $R O A$ is net income divided by averaged total assets, NOLC is deferred taxes divided by total assets, Size is the natural logarithm of total assets at year's end, TanA is fixed assets minus depreciation, the difference divided by total assets, $S E$ is selling/administrative expenses divided by revenue, $R D E$ is $R \& D$ expenses divided by total revenue, and IL is the median debt-to-assets ratio for all firms in the same industry. The average debt deviation is $-2.5 \%$, implying that, on average, firms were below the target debt level. According to the optimal leverage hypothesis, this means that firms should raise their debt ratio through share repurchasing.

The average stock option is $1 \%$. The literature indicates that stock options should be of concern to managers because of the threat of a reduced share price. During our sample period, $2 \%$ of the firms were associated with merger rumors. 


\section{Managerial Overconfidence and Share Repurchase}

Table 2 Summary statistics

\begin{tabular}{lccrrr}
\hline & Mean & Q1 & Q2 & Q3 & SD \\
\hline MOC & 0.46 & 0.25 & 0.50 & 0.67 & 0.32 \\
Number of repurchases & 3.74 & 1.00 & 3.00 & 5.00 & 3.69 \\
Shares repurchased (million shares) & 7.76 & 1.00 & 2.50 & 6.00 & 28.89 \\
Percentage of shares repurchased (\%) & 2.03 & 0.84 & 1.65 & 2.77 & 1.79 \\
Dollars repurchased (NTD million) & 162.71 & 0.00 & 63.10 & 90.48 & 1168.88 \\
Repurchase dollar percentage (\%) & 1.63 & 0.55 & 1.20 & 2.21 & 1.59 \\
Execution percentage (\%) & 70.08 & 41.53 & 85.06 & 100.00 & 33.91 \\
Price difference & 0.178 & -0.028 & 0.113 & 0.323 & 0.351 \\
B/M equity & 0.92 & 0.53 & 0.80 & 1.191 & 0.57 \\
ROE & 9.65 & 3.01 & 8.54 & 16.09 & 11.79 \\
FCF & 0.04 & 0.00 & 0.03 & 0.07 & 0.08 \\
Cash & 0.15 & 0.05 & 0.11 & 0.21 & 0.14 \\
Debt deviation & -2.50 & -9.58 & -0.60 & 4.40 & 12.10 \\
Stock options & 0.01 & 0.00 & 0.00 & 0.00 & 0.03 \\
INVO & 1.36 & 0.90 & 1.14 & 1.56 & 0.78 \\
D (takeover) & 0.02 & 0.00 & 0.00 & 0.00 & 0.15 \\
CGI & 5.829 & 5.00 & 6.00 & 7.00 & 1.97 \\
Dividend payout & 0.458 & 0.00 & 0.37 & 0.63 & 1.72 \\
CAR (-1,1) & 1.13 & -2.63 & 1.39 & 5.37 & 7.32 \\
CAR (-5,5) & -0.48 & -7.33 & 0.07 & 6.56 & 13.18 \\
CAR (0,20) & 5.07 & -3.50 & 4.93 & 13.26 & 15.59 \\
CAR (0,40) & 6.25 & -7.49 & 5.92 & 19.00 & 23.74 \\
CAR (0,60) & 6.87 & -11.93 & 6.46 & 22.90 & 31.42 \\
\hline
\end{tabular}

The sample from August 2000 through December 2008 was collected from the Treasury Stock Module of the Taiwan Economic Journal (TEJ). After excluding financial companies, there remains a total 2744 share repurchases. MOC denotes managerial overconfidence, defined as $a /(a+b)$, where $a$ is the number of times the words 'confident' and 'optimistic' appeared in the press portrayals and $b$ is the number of times the terms 'reliable', 'cautious', 'conservative', 'practical', 'frugal', 'steady', 'not confident' and 'not optimistic' appeared. The calculations are adjusted for managerial turnover. The source for the portrayals is TEJ's Company News Clip. Repurchase percentage is the number of repurchased shares divided by the total number of outstanding shares at the end of the previous year. Repurchase dollar percentage is dollars repurchased divided by the market value of the total equity at the end of the previous year. Execution percentage is the number of repurchased shares divided by the number of shares announced to be executed. Price difference is the difference between the median of the announced price range plus the average price 3 days after the program ends, the sum divided by the average price 3 days after the program ends $\left(\left(M P-P_{+3}\right) / P_{+3}\right)$. $\mathrm{B} / \mathrm{M}$ equity is the ratio of book equity to market equity at the end of the previous year. Return on equity (ROE) is net income divided by average book equity. Free cash flow (FCF) is earnings before depreciation minus the sum of taxes, interest expenses, preferred dividend, and cash dividend, the sum divided by total assets at the beginning of the program. Cash is the sum of cash available at the end of the program plus short-term investment divided by total assets at the end of the program. Debt deviation is the difference between current debt level and optimal debt level; it is estimated by the regression Debt* ${ }_{i t}=\beta_{0}+\beta_{1} M B_{i, t}+\beta_{2} S R T_{i(t-1)}+\beta_{3} R O A_{i t}+\beta_{4} \mathrm{NOLC}_{i t}+\beta_{5} \operatorname{Size}_{i t}+\beta_{6}$ TanA $_{i t}+\beta_{7} S E_{i t}+\beta_{8} R D E_{i t}+\beta_{9} I L_{i t}+\varepsilon_{i t}$, where Debt* is the optimal debt level, $M B$ is year-end market-to-book equity, $S R T$ is the annual return, $R O A$ is net income divided by the average of total assets, NOLC is deferred taxes divided by total assets, Size is the natural logarithm of total assets at year's end, TanA is fixed assets minus depreciation, the differencedivided by total assets, $S E$ is the sum of selling and administrative expenses divided by revenue; $R D E$ is R\&D expenses divided by total revenue, and $I L$ is the median debt-to-assets ratio for all firms in the same industry. Stock options is expected employee stock options divided by total outstanding shares at the end of the previous year. INVO is the sum of market equity and total debt divided by total assets at year's end. D(takeover) is a dummy that is assigned the value 1 if the firm is rumored to be an acquirer or a target in the current year or the previous year, 0 otherwise. The corporate governance index (CGI) is the sum of the following dummies: board control, supervisory control, voting-cash deviation, pledge ratio, related party sales, related party purchases, related party loans, related party guarantees (all 1 if smaller than the sample median, 0 otherwise), and cash flow rights and cash/voting ratio (both 1 if higher than the sample median, 0 otherwise). The possible range of CGI is 0 to 10 . Abnormal returns in the windows are gauged by the traditional event study with $\alpha$ and $\beta$ estimated using the returns from the 250 trading days prior to the announcement. Dividend payout is cash dividend divided by net income. 
If a firm is a potential merger target, it can repurchase shares to raise the margin price if the demand curve for shares is negatively sloped. The average payout can be considered an alternative to repurchasing as a way to expend cash. The average payout is $45.8 \%$ of total shares.

Using the traditional event study approach, we calculate the abnormal returns in different windows. Alternative windows $(-1,1),(-5,5),(0,20),(0$, $40)$, and $(0,60)$ are chosen to capture the impact of the information during the repurchase program. ${ }^{10}$ Window $(-5,5)$ captures the effect of board approval to the open-market repurchase, which usually takes place $4-5$ days after approval. Window $(0,40)$ represents the 2-month duration of the repurchase program. Window $(0,60)$ captures the overall market reaction after execution of the repurchase program. The corresponding average cumulated abnormal returns for the five windows are $1.16 \%,-0.29 \%, 4.97 \%, 6.10 \%$, and $6.70 \%$, respectively, reflecting a monotonic increase in abnormal returns.

\section{EMPIRICAL RESULTS}

Table 3 presents the results for MOC and market valuation. In panel A, the firms are divided into quintiles based on the firm's size and market-to-book equity. Panel A also gives means for the press-based overconfidence measures. The results show that, in general, medium-size firms and firms with high growth potential (high market-to-book equity) have the highest overconfidence scores. Assuming that firms behave according to the life cycle paradigm, the statistics indicate that managers of firms that have exhibited accelerated growth or achieved at least median growth exhibited the greatest overconfidence. These managers had a strong sense that their firm's shares were undervalued, and therefore, they were motivated to launch repurchase programs. However, compared to firms with low market-to-book equity, the firms with high market-tobook equity tended to be glamor stocks, which are relatively unlikely to be undervalued.

Panel B presents results on the firm's intrinsic value and how MOC is related to valuation of its stock. We use two approaches to measure the fair value of share repurchasing firms. In the first one, we calculate fair value of share repurchasing firms by exploiting price multiples, such as price-to-book and price-to-sales of non-announced industry peers that are similar in size to the firm in question (cf. Purnanandam and Swaminathan 2004). We then compare the resulting fair value $(V)$ to the average pre-announced price in window $(-10,6)(P)$ as follows:

$$
\begin{aligned}
& {\left[(P / V)_{\text {Book }}=(P / B)_{\text {Stock Repurchase Firm }} /(P / B)_{\text {Matching Firm }}\right]} \\
& {\left[(P / V)_{\text {Sales }}=(P / S)_{\text {Stock Repurchase Firm }} /(P / S)_{\text {Matching Firm }}\right]}
\end{aligned}
$$

10 We also conduct tests of whether the cumulative abnormal returns in these observation windows are significantly different from 0 . The results indicate that CAR $(0,20)$, CAR $(0,40)$, and $\operatorname{CAR}(0,60)$ are all positive and significant at the $1 \%$ level. 
Table 3 Managerial overconfidence and valuation

Panel A: Managerial overconfidence in different quintiles

\begin{tabular}{lcc}
\hline & Size & M/B \\
\hline 1 & 0.4148 & 0.4147 \\
2 & 0.4475 & 0.4645 \\
3 & 0.5002 & 0.4607 \\
4 & 0.4799 & 0.4718 \\
5 & 0.4624 & 0.5019 \\
\hline
\end{tabular}

Panel B: Managerial overconfidence and valuation

\begin{tabular}{|c|c|c|c|c|c|c|c|}
\hline & & \multicolumn{2}{|c|}{$(\mathrm{P} / \mathrm{V})_{\text {Book }}$} & \multicolumn{2}{|c|}{$(\mathrm{P} / \mathrm{V})_{\text {Sales }}$} & \multicolumn{2}{|c|}{$(\mathrm{P} / \mathrm{V})_{\mathrm{CS}}$} \\
\hline & & Mean & $t$-value & Mean & $t$-value & Mean & $t$-value \\
\hline MOC & $\mathrm{H}$ & 1.188 & 2.410 & 1.279 & 0.511 & 1.151 & 2.410 \\
\hline & $\mathrm{L}$ & 1.051 & $(0.016)^{* *}$ & 1.252 & $(0.609)$ & 1.061 & $(0.016)^{* *}$ \\
\hline
\end{tabular}

Panel C: Managerial overconfidence and attributes of share repurchases

\begin{tabular}{lccc}
\hline & \multicolumn{2}{c}{ MOC } & \multirow{2}{*}{$t$} \\
\cline { 2 - 3 } & $\mathrm{H}$ & $\mathrm{L}$ & \\
\hline Repurchases & 4.315 & 3.804 & $2.953^{* * *}$ \\
Percent shares repurchased & 2.066 & 1.898 & $2.544^{* *}$ \\
Repurchase dollar percentage & 1.626 & 1.549 & 1.524 \\
Execution percentage & 70.87 & 69.432 & 0.969 \\
Price difference & 0.214 & 0.155 & $3.511^{* * *}$ \\
\hline
\end{tabular}

In panel A, the sample is divided into quintiles based on firm size (total assets) and market-to-book equity, respectively. The average managerial overconfidence (MOC) for each size and market-tobook quintile is reported. In Panel B, managerial overconfidence is divided into high and low groups at the sample median. The tests of the differences in the valuation metrics between high and low managerial overconfidence are reported accordingly. The valuation metric, taken from Purnanandam and Swaminathan (2004), is the average pre-announced price of the sharerepurchasing firm in the window $(-10,6)$ (P) divided by the fair value estimated using price multiples (e.g., price-to-book and price-to-sales) of a non-announced industry peer that is similar in size to that firm $(\mathrm{V})$. That is, $\left[(\mathrm{P} / \mathrm{V})_{\text {Book }}=(\mathrm{P} / \mathrm{B})_{\text {Stock Repurchase Firm }} /(\mathrm{P} / \mathrm{B})_{\text {Matching Firm }}\right]$ and $\left[(\mathrm{P} / \mathrm{V})_{\text {Sales }}=\right.$ $\left.(\mathrm{P} / \mathrm{S})_{\text {Stock Repurchase Firm/ }}(\mathrm{P} / \mathrm{S})_{\text {Matching Firm }}\right]$. The third measure, taken from Rhodes-Kroph et al. (2005), is the fair value estimatedusing the following cross-sectional regression: $V_{i t}=\alpha_{0}+\alpha_{1} b_{i t}+\alpha_{2} \mathrm{NI}^{+}{ }_{i t}+$ $\alpha_{3} I_{(<0)}(N I)^{+}{ }_{i t}+\alpha_{4} L E V_{i t}+\varepsilon_{i}$, where $b$ is the book value of the firm's assets, $N I$ is net income, and $L E V$ is the leverage ratio. $(\mathrm{P} / \mathrm{V})_{\mathrm{CS}}$ is the average price in window $(-10,-6)$ divided by the fair value estimated from the cross-sectional regression. $(\mathrm{P} / \mathrm{V})_{\text {Book }}(\mathrm{P} / \mathrm{V})_{\text {sales, }}$ and $(\mathrm{P} / \mathrm{V})_{\mathrm{CS}}$ are valuation metrics, in the sense that firms are overvalued (undervalued) when the value of the variable takes a value higher (lower) than 1. Panel C reports tests of the mean differences of the attribute variables between high and low managerial overconfidence. The attribute variables are number of repurchases per firm, percentage of shares repurchased, repurchase dollar percentage, execution percentage, and price difference). $* * *, * *$, and $*$ denote significance at the $1 \%, 5 \%$, and $10 \%$ levels, respectively.

The second approach is to calculate the fair value using the following crosssectional regression (cf. Rhodes-Kroph et al. 2005):

$$
V_{i t}=\alpha_{0}+\alpha_{1} b_{i t}+\alpha_{2} N I^{+}{ }_{i t}+\alpha_{3} I_{(<0)}(N I)^{+}{ }_{i t}+\alpha_{4} L E V_{i t}+\varepsilon_{i}
$$


where $b$ is the book value of the firm's assets, $N I$ is its net income, and LEV is the leverage ratio.

$(P / V)_{\mathrm{CS}}$ is the ratio of the average price in window $(-10,-6)$ to the fair value estimated from the cross-sectional regression. $(P / V)_{\text {Book, }}(P / V)_{\text {sales, }}$ and $(P / V)_{\mathrm{CS}}$ all reflect overvaluation if they are greater than 1 and undervaluation if they are less than 1.

The results in panel B indicate that the average $(P / V)_{\text {Book }}$ for high-MOC firms (1.188) is significantly higher than for low-MOC firms (1.051). The average $(P / V)_{\text {sales }}$ for high-MOC firms (1.279) is also higher than for low-MOC firms (1.252), although the difference is not significant. Using the alternative metric from Rhodes-Kroph et al. (2005), we also find that the average $(P / V)_{\mathrm{CS}}$ is higher for high-MOC firms than for their low-MOC counterparts. The overall results indicate that firms with overconfident managers are less likely to be undervalued than other firms.

Panel C presents other results bearing on the relation between MOC and the attributes of a share repurchase program. These attributes are number of repurchases per firm, percentage of total shares repurchased, percentage of the total dollar amount repurchased, percentage of repurchases executed, and price difference. Results from a univariate test show that high-MOC firms are associated with more share repurchase programs (4.315) than low-MOC firms (3.804). The percentage of shares repurchased is also higher for high-MOC firms $(2.066 \%)$ than for low-MOC firms (1.898\%). The price difference, defined as the difference between the median of the announced price range and the average price 3 days after the program ends, is higher for high-MOC firms (0.214) than for low-MOC firms (0.155). High-MOC firms, on average, are also associated with a higher percentage of the total value of the repurchase, as well as a higher execution rate, than low-MOC firms. However, the differences are not significant.

The overall results from Table 3 indicate that high-MOC firms are less likely than low-MOC firms to be undervalued. High-MOC firms launch more buyback offers to claim a higher percentage of shares to be repurchased, and they set a higher target price. Tests of differences between medians lead to the same conclusions as above.

The empirical model cited by Dittmar (2000) is formulated as follows:

$$
\begin{aligned}
S R_{i t}= & \beta_{0}+\beta_{1} \text { MOC }_{i, t}+\beta_{2} \text { Size }_{i, t}+\beta_{3} R O E_{i, t}+\beta_{4} B M_{i, t}+\beta_{5} \text { Deviation }_{i,(t-1)} \\
& +\beta_{6} \text { Options }_{i,(t-1)}+\beta_{7} \text { Cash }_{i, t}+\beta_{8} F C F_{i, t}+\beta_{9} I N V O_{i, t}+\beta_{10} D(\text { Takeover })_{i,(t-1)} \\
& +\beta_{11} \text { Payout }_{i,(t-1)}+\beta_{12} \text { CGI }_{i, t}+\varepsilon_{i, t}
\end{aligned}
$$

where $S R$ represents the attributes of the repurchase program, MOC is MOC, Size is the natural logarithm of the firm's assets, $B M$ denotes book-to-market equity, $R O E$ is the return on earnings, FCF is free cash flow (defined as earnings before taxes plus depreciation, minus the sum of taxes plus interest plus cash dividends, all divided by initial assets), and Cash is cash on hand divided by initial assets. Options denotes the expected employee stock options divided by the total 
outstanding shares before the end of the year, $I N V O$ is the sum of market equity plus total debt divided by total assets at year's end. Takeover is a dummy that is assigned a value 1 when the underlying firm is associated with a rumor of being an acquirer or a target in the current year or previous year, 0 otherwise. These variables are included in the models to control for other factors that might motivate the launching of a share repurchase program.

CGI (corporate governance index) is included in the model to assess whether corporate governance plays a counterbalancing role in deterring MOC in launching share repurchase programs. Consolidating different variables in a composite index is a way to comprehensively capture the overall quality of a firm's governance structure (Boehren and Oedegaard 2003). The CGI is constructed by summing the following dummies: board control, supervisory control, voting-cash deviation, pledge ratio, related party sales, related party purchases, related party loans, and related party guarantees (all coded 1 if smaller than the sample median, 0 otherwise), and cash flow rights and the cash/voting ratio (both coded 1 if higher than the sample median, 0 otherwise). Therefore, CGI has a range of 0 to 10. Finally, Deviation is the difference between the firm's debt ratio and the optimal debt ratio, estimated using the model reported by Hovakimain et al. (2004).

In Table 4, we report tobit regressions of the percentages of shares repurchased. MOC is positively correlated with this percentage. Size is negatively correlated with the claimed portion of the repurchased shares. A possible explanation of this result is that large firms are more likely than small firms to be the focal point of investors and are therefore less likely to be undervalued by the market.

We also find that firms with high book-to-market equity tended to launch larger share repurchase programs than other firms. This finding is consistent with the undervaluation hypothesis. Again, we find that debt deviation is positively correlated with the percentage of shares repurchased, which is inconsistent with both the optimal leverage hypothesis and the overconfidence hypothesis.

In Table 5 we present tobit regressions of the percentage dollar value of the repurchased shares compared to total shares, an alternative measure of the scale of a share repurchase program that simultaneously considers both the number of shares and the share price. The results show that overconfidence is positively correlated with the dollar value of the repurchased shares. The results with the other control variables are qualitatively similar to those reported in Table 6 below. The only exception is that takeover threat is positively correlated with the dollar value of the repurchased shares, indicating that firms facing such a threat tend to launch large share repurchase programs.

The results from Tables 4 and 5 support our speculation that MOC is a major force driving managers to launch large share repurchase programs. Moreover, an examination of data related to the hypotheses that explain why a firm would be expected to launch a share repurchase program supports the undervaluation hypothesis, in the sense that the firms that are neglected by the market (i.e., those with high book-to-market equity and low investment potential) tend to 
Table 4 Percentage of shares repurchased and managerial overconfidence

\begin{tabular}{lccccc}
\hline & Model 1 & Model 2 & Model 3 & Model 4 & Model 5 \\
& $(N=2003)$ & $(N=2003)$ & $(N=2003)$ & $(N=2003)$ & $(N=2003)$ \\
\hline Intercept & 7.031 & 6.305 & 6.455 & 6.329 & 6.967 \\
MOC & $(13.713)^{* * *}$ & $(12.115)^{* * *}$ & $(12.435)^{* * *}$ & $(12.097)^{* * *}$ & $(13.067)^{* * *}$ \\
& 0.262 & 0.240 & 0.241 & 0.243 & 0.247 \\
Size & $(2.301)^{* *}$ & $(2.099)^{* *}$ & $(2.107)^{* *}$ & $(2.123)^{* *}$ & $(2.178)^{* *}$ \\
& -0.329 & -0.316 & -0.314 & -0.316 & -0.320 \\
BM & $(-11.549)^{* * *}$ & $(-10.855)^{* * *}$ & $(-10.789)^{* * *}$ & $(-10.853)^{* * *}$ & $(-11.075)^{* * *}$ \\
& & 0.176 & & 0.161 & -0.055 \\
ROE & & $(2.202)^{* *}$ & & $(1.854)^{*}$ & $(-0.577)$ \\
& & & -0.005 & -0.002 & 0.007 \\
FCF & & & $(-1.266)$ & $(-0.442)$ & $(1.739)^{*}$ \\
& & 0.367 & 0.303 & 0.434 & 0.834 \\
Cash & & $(0.599)$ & $(0.482)$ & $(0.687)$ & $(1.321)$ \\
Debt deviation & 0.005 & $(1.464)$ & $(1.163)$ & $(1.512)$ & $(2.570)^{* *}$ \\
& $(1.638)$ & $(2.016) * *$ & $(1.746)^{*}$ & $(2.058)^{* *}$ & $(1.661)^{*}$ \\
Stock options & 0.276 & 0.057 & -0.027 & 0.051 & 0.192 \\
& $(0.288)$ & $(0.059)$ & $(-0.028)$ & $(0.053)$ & $(0.201)$ \\
INVO & -0.207 & & & & -0.378 \\
& $(-4.318)^{* * *}$ & & & & $(-5.328)^{* * *}$ \\
D (takeover) & 0.296 & 0.288 & 0.269 & 0.284 & 0.249 \\
CGI & $(1.325)$ & $(1.280)$ & $(1.196)$ & $(1.263)$ & $(1.115)$ \\
& 0.015 & 0.016 & 0.020 & 0.016 & 0.012 \\
Dividend payout & $(0.670)$ & $(0.681)$ & $(0.883)$ & $(0.695)$ & $(0.551)$ \\
Yearly fixed & 0.003 & 0.003 & 0.006 & 0.004 & 0.003 \\
effect & $(0.154)$ & $(0.193)$ & $(0.331)$ & $(0.214)$ & $(0.148)$ \\
Adjusted $R^{2}$ & Yes & Yes & Yes & Yes & Yes \\
\hline & 0.074 & 0.067 & 0.065 & 0.067 & 0.079 \\
\hline
\end{tabular}

This table reports the regression of percentage of shares repurchased on managerial overconfidence. The dependent variable is the number of shares repurchased divided by the total outstanding shares at the end of the previous year. The independent variable, MOC, and other variables are defined as in Table 2. In each cell, the regression coefficients and $z$-statistics (in parentheses) are in upper and lower case respectively. $* * *, * *$, and $*$ denote significance at the $1 \%$, $5 \%$, and $10 \%$ levels, respectively.

be the ones that launch large repurchase programs. The takeover deterrence hypothesis is also supported, in that firms that were merger targets tended to launch large share repurchase programs as a way to deter possible raiders. However, the excess capital hypothesis, the leverage adjustment hypothesis, and the management incentive hypothesis are not supported by the data. These hypotheses are relevant to a firm's' decision of whether to launch a share repurchase program, but not the scale of the program.

Table 6 shows how MOC is related to the percentage of repurchase programs that are executed. The results are consistent with our intuition that 
Table 5 Dollars repurchased and managerial overconfidence

\begin{tabular}{|c|c|c|c|c|c|}
\hline & $\begin{array}{c}\text { Model } 1 \\
(N=2003)\end{array}$ & $\begin{array}{c}\text { Model } 2 \\
(N=2003)\end{array}$ & $\begin{array}{c}\text { Model } 3 \\
(N=2003)\end{array}$ & $\begin{array}{c}\text { Model } 4 \\
(N=2003)\end{array}$ & $\begin{array}{c}\text { Model } 5 \\
(N=2003)\end{array}$ \\
\hline Intercept & $\begin{array}{c}5.614 \\
(11.558)^{* * *}\end{array}$ & $\begin{array}{l}4.527 \\
(9.232)^{* * *}\end{array}$ & $\begin{array}{c}4.989 \\
(10.105)^{* * * *}\end{array}$ & $\begin{array}{l}4.576 \\
(9.284)^{* * *}\end{array}$ & $\begin{array}{l}4.973 \\
(9.861)^{* * *}\end{array}$ \\
\hline MOC & $\begin{array}{l}0.306 \\
(2.841) * * *\end{array}$ & $\begin{array}{l}0.306 \\
(2.843) * * *\end{array}$ & $\begin{array}{l}0.307 \\
(2.821) * * *\end{array}$ & $\begin{array}{l}0.312 \\
(2.898)^{* * *}\end{array}$ & $\begin{array}{l}0.315 \\
(2.934) * * *\end{array}$ \\
\hline Size & $\begin{array}{c}-0.278 \\
(-10.284)^{* * *}\end{array}$ & $\begin{array}{l}-0.268 \\
(-9.779)^{* * *}\end{array}$ & $\begin{array}{l}-0.262 \\
(-9.474) * * *\end{array}$ & $\begin{array}{l}-0.268 \\
(-9.776)^{* * *}\end{array}$ & $\begin{array}{l}-0.271 \\
(-9.900) * * *\end{array}$ \\
\hline $\mathrm{BM}$ & & $\begin{array}{l}0.554 \\
(7.372)^{* * * *}\end{array}$ & & $\begin{array}{l}0.523 \\
(6.413)^{* * *}\end{array}$ & $\begin{array}{c}0.389 \\
(4.330)^{* * *}\end{array}$ \\
\hline ROE & & & $\begin{array}{l}-0.013 \\
(-3.725) * * *\end{array}$ & $\begin{array}{l}-0.004 \\
(-0.961)\end{array}$ & $\begin{array}{c}0.002 \\
(0.531)\end{array}$ \\
\hline FCF & & $\begin{array}{l}-0.522 \\
(-0.902)\end{array}$ & $\begin{array}{l}-0.813 \\
(-1.361)\end{array}$ & $\begin{array}{l}-0.385 \\
(-0.647)\end{array}$ & $\begin{array}{l}-0.136 \\
(-0.228)\end{array}$ \\
\hline Cash & & $\begin{array}{c}0.432 \\
(1.515)\end{array}$ & $\begin{array}{c}0.100 \\
(0.350)\end{array}$ & $\begin{array}{c}0.471 \\
(1.635)\end{array}$ & $\begin{array}{l}0.678 \\
(2.313)^{* *}\end{array}$ \\
\hline Debt deviation & $\begin{array}{c}0.001 \\
(0.422)\end{array}$ & $\begin{array}{l}0.006 \\
(1.910)^{*}\end{array}$ & $\begin{array}{c}0.002 \\
(0.852)\end{array}$ & $\begin{array}{l}0.006 \\
(2.023) * *\end{array}$ & $\begin{array}{l}0.005 \\
(1.757)^{*}\end{array}$ \\
\hline Stock options & $\begin{array}{c}0.071 \\
(0.078)\end{array}$ & $\begin{array}{c}0.030 \\
(0.033)\end{array}$ & $\begin{array}{l}-0.236 \\
(-0.258)\end{array}$ & $\begin{array}{c}0.017 \\
(0.019)\end{array}$ & $\begin{array}{c}0.106 \\
(0.117)\end{array}$ \\
\hline INVO & $\begin{array}{l}-0.333 \\
(-7.323) * * *\end{array}$ & & & & $\begin{array}{l}-0.235 \\
(-3.506) * * *\end{array}$ \\
\hline D (takeover) & $\begin{array}{l}0.413 \\
(1.953)^{*}\end{array}$ & $\begin{array}{l}0.481 \\
(2.269)^{* *}\end{array}$ & $\begin{array}{l}0.424 \\
(1.983) * *\end{array}$ & $\begin{array}{l}0.473 \\
(2.232)^{* *}\end{array}$ & $\begin{array}{l}0.451 \\
(2.135)^{* *}\end{array}$ \\
\hline CGI & $\begin{array}{c}0.031 \\
(1.453)\end{array}$ & $\begin{array}{c}0.025 \\
(1.168)\end{array}$ & $\begin{array}{c}0.039 \\
(1.826)^{*}\end{array}$ & $\begin{array}{c}0.026 \\
(1.199)\end{array}$ & $\begin{array}{c}0.024 \\
(1.104)\end{array}$ \\
\hline Dividend payout & $\begin{array}{c}0.006 \\
(0.365)\end{array}$ & $\begin{array}{c}0.002 \\
(0.133)\end{array}$ & $\begin{array}{c}0.010 \\
(0.577)\end{array}$ & $\begin{array}{c}0.003 \\
(0.179)\end{array}$ & $\begin{array}{c}0.002 \\
(0.135)\end{array}$ \\
\hline Yearly fixed effect & Yes & Yes & Yes & Yes & Yes \\
\hline Adjusted $R^{2}$ & 0.106 & 0.109 & 0.090 & 0.109 & 0.114 \\
\hline
\end{tabular}

This table reports the regression of percentage of dollars repurchased on managerial overconfidence. The dependent variable is dollars repurchased divided by the total market value of the equity at the end of the previous year. The independent variable, MOC, and other variables are defined as in Table 2. In each cell, the regression coefficients and $z$-statistics (in parentheses) are in upper and lower case, respectively. $* * *, * *$, and $*$ denote significance at the $1 \%, 5 \%$, and $10 \%$ levels, respectively.

overconfident managers tend to execute a high proportion of the programs they have announced. MOC is significantly and positively correlated with the execution rate, and investment opportunity is negatively correlated with the execution rate. The two correlations lend further support to the undervaluation hypothesis because firms with insufficient investment opportunities tend to own out-of-favor stocks that are undervalued by the market. To keep the price at the anticipated level, overconfident managers tend to execute a high percentage of their claimed buyback.

Investment opportunity and takeover threat are both negatively correlated with the percentage of repurchase programs executed. A possible explanation is 
Table 6 Execution of repurchases and managerial overconfidence

\begin{tabular}{|c|c|c|c|c|c|}
\hline & $\begin{array}{c}\text { Model } 1 \\
(N=2003)\end{array}$ & $\begin{array}{c}\text { Model } 2 \\
(N=2003)\end{array}$ & $\begin{array}{l}\text { Model } 3 \\
(N=2003)\end{array}$ & $\begin{array}{c}\text { Model } 4 \\
(N=2003)\end{array}$ & $\begin{array}{l}\text { Model } 5 \\
(N=2003)\end{array}$ \\
\hline Intercept & $\begin{array}{l}80.032 \\
(7.181)^{* * *}\end{array}$ & $\begin{array}{l}74.332 \\
(6.631) * * *\end{array}$ & $\begin{array}{l}74.625 \\
(6.694) * * *\end{array}$ & $\begin{array}{l}76.005 \\
(6.748) * * *\end{array}$ & $\begin{array}{l}86.450 \\
(7.439) * * *\end{array}$ \\
\hline MOC & $\begin{array}{l}6.208 \\
(2.512) * *\end{array}$ & $\begin{array}{l}6.130 \\
(2.491) * *\end{array}$ & $\begin{array}{l}6.290 \\
(2.554)^{* *}\end{array}$ & $\begin{array}{l}6.372 \\
(2.585) * * *\end{array}$ & $\begin{array}{l}6.139 \\
(2.480) * *\end{array}$ \\
\hline Size & $\begin{array}{l}-0.673 \\
(-1.085)\end{array}$ & $\begin{array}{l}-0.453 \\
(-0.724)\end{array}$ & $\begin{array}{l}-0.531 \\
(-0.852)\end{array}$ & $\begin{array}{l}-0.450 \\
(-0.721)\end{array}$ & $\begin{array}{l}-0.660 \\
(-1.048)\end{array}$ \\
\hline $\mathrm{BM}$ & & $\begin{array}{l}-1.400 \\
(-0.810)\end{array}$ & & $\begin{array}{l}-2.457 \\
(-1.310)\end{array}$ & $\begin{array}{l}-5.171 \\
(-2.496) * *\end{array}$ \\
\hline ROE & & & $\begin{array}{l}-0.101 \\
(-1.314)\end{array}$ & $\begin{array}{l}-0.121 \\
(-1.450)\end{array}$ & $\begin{array}{c}0.012 \\
(0.125)\end{array}$ \\
\hline FCF & & $\begin{array}{l}-19.860 \\
(-1.509)\end{array}$ & $\begin{array}{l}-13.582 \\
(-1.008)\end{array}$ & $\begin{array}{l}-15.107 \\
(-1.115)\end{array}$ & $\begin{array}{l}-6.704 \\
(-0.488)\end{array}$ \\
\hline Cash & & $\begin{array}{l}-9.447 \\
(-1.457)\end{array}$ & $\begin{array}{l}-5.972 \\
(-0.934)\end{array}$ & $\begin{array}{l}-8.170 \\
(-1.249)\end{array}$ & $\begin{array}{l}-3.103 \\
(-0.459)\end{array}$ \\
\hline Debt deviation & $\begin{array}{c}0.024 \\
(0.389)\end{array}$ & $\begin{array}{l}-0.014 \\
(-0.215)\end{array}$ & $\begin{array}{c}0.022 \\
(0.328)\end{array}$ & $\begin{array}{l}-0.002 \\
(-0.024)\end{array}$ & $\begin{array}{l}-0.018 \\
(-0.264)\end{array}$ \\
\hline Stock options & $\begin{array}{l}35.275 \\
(1.690) *\end{array}$ & $\begin{array}{l}33.383 \\
(1.595)\end{array}$ & $\begin{array}{l}34.483 \\
(1.646) *\end{array}$ & $\begin{array}{c}33.041 \\
(1.580)\end{array}$ & $\begin{array}{c}34.211 \\
(1.639)\end{array}$ \\
\hline INVO & $\begin{array}{l}-3.138 \\
(-3.015) * * *\end{array}$ & & & & $\begin{array}{l}-4.944 \\
(-3.197) * * *\end{array}$ \\
\hline D (takeover) & $\begin{array}{l}-12.397 \\
(-2.551)^{* *}\end{array}$ & $\begin{array}{l}-12.101 \\
(-2.477) * *\end{array}$ & $\begin{array}{l}-12.066 \\
(-2.464)^{* *}\end{array}$ & $\begin{array}{l}-12.355 \\
(-2.529)^{* *}\end{array}$ & $\begin{array}{l}-12.770 \\
(-2.621) * * *\end{array}$ \\
\hline CGI & $\begin{array}{l}-0.377 \\
(-0.766)\end{array}$ & $\begin{array}{l}-0.276 \\
(-0.559)\end{array}$ & $\begin{array}{l}-0.237 \\
(-0.483)\end{array}$ & $\begin{array}{l}-0.249 \\
(-0.504)\end{array}$ & $\begin{array}{l}-0.283 \\
(-0.573)\end{array}$ \\
\hline Dividend payout & $\begin{array}{c}0.635 \\
(1.642)\end{array}$ & $\begin{array}{c}0.662 \\
(1.704) *\end{array}$ & $\begin{array}{c}0.639 \\
(1.643)\end{array}$ & $\begin{array}{c}0.690 \\
(1.775)^{*}\end{array}$ & $\begin{array}{c}0.673 \\
(1.739) *\end{array}$ \\
\hline $\begin{array}{l}\text { Yearly fixed effect } \\
\text { Adjusted } R^{2}\end{array}$ & $\begin{array}{c}\text { Yes } \\
0.018\end{array}$ & $\begin{array}{c}\text { Yes } \\
0.016\end{array}$ & $\begin{array}{c}\text { Yes } \\
0.016\end{array}$ & $\begin{array}{c}\text { Yes } \\
0.016\end{array}$ & $\begin{array}{r}\text { Yes } \\
0.019\end{array}$ \\
\hline
\end{tabular}

This table reports the regression of percentage of announced repurchase shares executed on managerial overconfidence. The dependent variable is the percentage of share repurchases executed. The independent variable, MOC, and other variables are defined as in Table 2. In each cell, the regression coefficients and $z$-statistics (in parentheses) are in upper and lower case, respectively. $* * *, * *$, and $*$ denote significance at the $1 \%, 5 \%$, and $10 \%$ levels respectively.

that the repurchase signal is so strong that the price level set by the overconfident managers is quickly reached. The cash not spent for the unexecuted program can be saved for other promising investments. Because a low execution rate can lead to the realization of the anticipated price level, the firm can free itself from the threat of a takeover.

The results in Table 7 address how MOC affects the number of share repurchase programs per firm. As shown in Table 1, more than 70\% of the announcing firms launched more than one program. The theoretical literature suggests that managers become overconfident as a result of prior experiences. If this is the case, the success with prior share repurchase programs should increase mangers' confidence and encourage them to launch more repurchase programs. 
Table 7 Number of repurchases and managerial overconfidence

\begin{tabular}{|c|c|c|c|c|c|}
\hline & $\begin{array}{c}\text { Model } 1 \\
(N=2004)\end{array}$ & $\begin{array}{c}\text { Model } 2 \\
(N=2025)\end{array}$ & $\begin{array}{c}\text { Model } 3 \\
(N=2038)\end{array}$ & $\begin{array}{c}\text { Model } 4 \\
(N=2025)\end{array}$ & $\begin{array}{c}\text { Model } 5 \\
(N=2004)\end{array}$ \\
\hline Intercept & $\begin{array}{l}-0.939 \\
(-3.256)^{* * *}\end{array}$ & $\begin{array}{l}-1.702 \\
(-5.802)^{* * * *}\end{array}$ & $\begin{array}{l}-1.418 \\
(-4.899) * * *\end{array}$ & $\begin{array}{l}-1.524 \\
(-5.223) * * *\end{array}$ & $\begin{array}{l}-1.115 \\
(-3.693)^{* * *}\end{array}$ \\
\hline MOC & $\begin{array}{c}0.048 \\
(0.744)\end{array}$ & $\begin{array}{c}0.046 \\
(0.706)\end{array}$ & $\begin{array}{c}0.074 \\
(1.141)\end{array}$ & $\begin{array}{c}0.071 \\
(1.099)\end{array}$ & $\begin{array}{c}0.067 \\
(1.037)\end{array}$ \\
\hline Size & $\begin{array}{c}-0.174 \\
(-10.895) \text { *** }\end{array}$ & $\begin{array}{c}-0.182 \\
(-11.128)^{* * *}\end{array}$ & $\begin{array}{c}-0.187 \\
(-11.521)^{* * *}\end{array}$ & $\begin{array}{c}-0.182 \\
(-11.251)^{* * *}\end{array}$ & $\begin{array}{c}-0.177 \\
(-10.898) * * *\end{array}$ \\
\hline BM & & $\begin{array}{l}0.300 \\
(6.619) * * *\end{array}$ & & $\begin{array}{l}0.188 \\
(3.863)^{* * * *}\end{array}$ & $\begin{array}{c}0.064 \\
(1.167)\end{array}$ \\
\hline ROE & & & $\begin{array}{l}-0.016 \\
(-7.986)^{* * *}\end{array}$ & $\begin{array}{l}-0.013 \\
(-5.886)^{* * *}\end{array}$ & $\begin{array}{l}-0.008 \\
(-3.358)^{* * *}\end{array}$ \\
\hline FCF & & $\begin{array}{l}-1.154 \\
(-3.293)^{* * *}\end{array}$ & $\begin{array}{l}-0.821 \\
(-2.308)^{* *}\end{array}$ & $\begin{array}{l}-0.664 \\
(-1.862) *\end{array}$ & $\begin{array}{l}-0.428 \\
(-1.191)\end{array}$ \\
\hline Cash & & $\begin{array}{l}-0.231 \\
(-1.358)\end{array}$ & $\begin{array}{l}-0.252 \\
(-1.513)\end{array}$ & $\begin{array}{l}-0.097 \\
(-0.573)\end{array}$ & $\begin{array}{c}0.008 \\
(-0.045)\end{array}$ \\
\hline Debt deviation & $\begin{array}{l}-0.011 \\
(-6.886)^{* * *}\end{array}$ & $\begin{array}{l}-0.01 \\
(-5.827) * * *\end{array}$ & $\begin{array}{l}-0.01 \\
(-5.924)^{* * *}\end{array}$ & $\begin{array}{l}-0.009 \\
(-5.065)^{* * *}\end{array}$ & $\begin{array}{l}-0.01 \\
(-5.537) * * *\end{array}$ \\
\hline Stock options & $\begin{array}{l}-0.511 \\
(-0.926)\end{array}$ & $\begin{array}{l}-0.522 \\
(-0.943)\end{array}$ & $\begin{array}{l}-0.635 \\
(-1.147)\end{array}$ & $\begin{array}{l}-0.568 \\
(-1.032)\end{array}$ & $\begin{array}{l}-0.529 \\
(-0.963)\end{array}$ \\
\hline INVO & $\begin{array}{c}-0.33 \\
(-11.044) * * *\end{array}$ & & & & $\begin{array}{l}-0.208 \\
(-4.717) * * *\end{array}$ \\
\hline $\mathrm{D}$ (takeover) & $\begin{array}{l}-0.49 \\
(-3.862)^{* * *}\end{array}$ & $\begin{array}{l}-0.417 \\
(-3.247)^{* * *}\end{array}$ & $\begin{array}{l}-0.465 \\
(-3.630)^{* * *}\end{array}$ & $\begin{array}{l}-0.447 \\
(-3.504)^{* * *}\end{array}$ & $\begin{array}{l}-0.468 \\
(-3.693) * * *\end{array}$ \\
\hline CGI & $\begin{array}{l}-0.013 \\
(-1.022)\end{array}$ & $\begin{array}{l}-0.016 \\
(-1.244)\end{array}$ & $\begin{array}{l}-0.008 \\
(-0.589)\end{array}$ & $\begin{array}{l}-0.013 \\
(-1.014)\end{array}$ & $\begin{array}{l}-0.012 \\
(-0.921)\end{array}$ \\
\hline Dividend payout & $\begin{array}{c}0.008 \\
(0.787)\end{array}$ & $\begin{array}{c}0.006 \\
(0.619)\end{array}$ & $\begin{array}{c}0.012 \\
(1.175)\end{array}$ & $\begin{array}{c}0.009 \\
(0.906)\end{array}$ & $\begin{array}{c}0.008 \\
(0.842)\end{array}$ \\
\hline $\begin{array}{l}\text { Yearly fixed } \\
\text { effect }\end{array}$ & Yes & Yes & Yes & Yes & Yes \\
\hline Adjusted $R^{2}$ & 0.267 & 0.248 & 0.261 & 0.264 & 0.273 \\
\hline
\end{tabular}

This table reports the regression of the number of share repurchase programs on managerial overconfidence. The dependent variable is the natural logarithm of the number of share repurchase programs. The independent variable, MOC, and other variables are defined as in Table 2 . In each cell, the regression coefficients and $z$-statistics (in parentheses) are in upper and lower case, respectively. $* * *, * *$, and $*$ denote significance at the $1 \%, 5 \%$, and $10 \%$ levels, respectively.

However, although Table 7 exhibits a positive correlation between the numbers of repurchase programs per firm and MOC, it is not statistically significant.

The results in Table 8 relate MOC to price differences, defined as the change from the median of the announced price range to the average price after the program ends. It is supposed to be positively correlated with the level of MOC because the market sooner or later recognizes that the overly optimistic signal emitted by overconfident managers must be rectified. The higher the level of MOC, the larger the needed rectification.

The results generally support this conjecture, as MOC is positively and significantly correlated with the price difference. Moreover, debt deviation is 
Table 8 Price difference and managerial overconfidence

\begin{tabular}{|c|c|c|c|c|c|}
\hline & $\begin{array}{c}\text { Model } 1 \\
(N=1642)\end{array}$ & $\begin{array}{c}\text { Model } 2 \\
(N=1649)\end{array}$ & $\begin{array}{c}\text { Model } 3 \\
(N=1656)\end{array}$ & $\begin{array}{c}\text { Model } 4 \\
(N=1649)\end{array}$ & $\begin{array}{c}\text { Model } 5 \\
(N=1642)\end{array}$ \\
\hline Intercept & $\begin{array}{l}0.452 \\
(4.103)^{* * *}\end{array}$ & $\begin{array}{l}0.554 \\
(4.953) * * *\end{array}$ & $\begin{array}{l}0.541 \\
(4.873) * * *\end{array}$ & $\begin{array}{l}0.556 \\
(4.953) * * *\end{array}$ & $\begin{array}{l}0.466 \\
(4.051)^{* * *}\end{array}$ \\
\hline MOC & $\begin{array}{l}0.049 \\
(2.005) * *\end{array}$ & $\begin{array}{l}0.051 \\
(2.118)^{* *}\end{array}$ & $\begin{array}{l}0.049 \\
(2.012)^{* *}\end{array}$ & $\begin{array}{l}0.052 \\
(2.125) * *\end{array}$ & $\begin{array}{l}0.049 \\
(2.016)^{* *}\end{array}$ \\
\hline Size & $\begin{array}{l}-0.005 \\
(-0.880)\end{array}$ & $\begin{array}{l}-0.009 \\
(-1.453)\end{array}$ & $\begin{array}{l}-0.009 \\
(-1.392)\end{array}$ & $\begin{array}{l}-0.009 \\
(-1.446)\end{array}$ & $\begin{array}{l}-0.007 \\
(-1.158)\end{array}$ \\
\hline $\mathrm{BM}$ & & $\begin{array}{l}-0.008 \\
(-0.486)\end{array}$ & & $\begin{array}{l}-0.010 \\
(-0.529)\end{array}$ & $\begin{array}{c}0.014 \\
(0.692)\end{array}$ \\
\hline ROE & & & $\begin{array}{c}0.000 \\
(-0.169)\end{array}$ & $\begin{array}{c}0.000 \\
(-0.211)\end{array}$ & $\begin{array}{l}-0.001 \\
(-1.280)\end{array}$ \\
\hline FCF & & $\begin{array}{c}0.135 \\
(1.031)\end{array}$ & $\begin{array}{c}0.156 \\
(1.173)\end{array}$ & $\begin{array}{c}0.142 \\
(1.051)\end{array}$ & $\begin{array}{c}0.048 \\
(0.354)\end{array}$ \\
\hline Cash & & $\begin{array}{l}-0.078 \\
(-1.208)\end{array}$ & $\begin{array}{l}-0.067 \\
(-1.053)\end{array}$ & $\begin{array}{l}-0.075 \\
(-1.158)\end{array}$ & $\begin{array}{l}-0.108 \\
(-1.623)\end{array}$ \\
\hline Debt deviation & $\begin{array}{l}0.002 \\
(3.541)^{* * * *}\end{array}$ & $\begin{array}{l}0.002 \\
(3.023) * * *\end{array}$ & $\begin{array}{l}0.002 \\
(3.221) * * *\end{array}$ & $\begin{array}{l}0.002 \\
(3.021)^{* * *}\end{array}$ & $\begin{array}{l}0.002 \\
(3.245) * * *\end{array}$ \\
\hline Stock options & $\begin{array}{c}0.164 \\
(0.845)\end{array}$ & $\begin{array}{c}0.188 \\
(0.965)\end{array}$ & $\begin{array}{l}0.194 \\
(1.001)\end{array}$ & $\begin{array}{l}0.187 \\
(0.963)\end{array}$ & $\begin{array}{c}0.177 \\
(0.912)\end{array}$ \\
\hline INVO & $\begin{array}{l}0.021 \\
(2.011) * *\end{array}$ & & & & $\begin{array}{l}0.043 \\
(2.857) * * *\end{array}$ \\
\hline D (takeover) & $\begin{array}{l}0.100 \\
(2.083)^{* *}\end{array}$ & $\begin{array}{l}0.099 \\
(2.050) * *\end{array}$ & $\begin{array}{l}0.099 \\
(2.058) * *\end{array}$ & $\begin{array}{l}0.099 \\
(2.042) * *\end{array}$ & $\begin{array}{l}0.102 \\
(2.120)^{* *}\end{array}$ \\
\hline CGI & $\begin{array}{l}-0.005 \\
(-0.940)\end{array}$ & $\begin{array}{l}-0.005 \\
(-1.000)\end{array}$ & $\begin{array}{l}-0.005 \\
(-0.983)\end{array}$ & $\begin{array}{l}-0.005 \\
(-0.988)\end{array}$ & $\begin{array}{l}-0.004 \\
(-0.914)\end{array}$ \\
\hline Dividend payout & $\begin{array}{l}-0.012 \\
(-1.731)^{*}\end{array}$ & $\begin{array}{l}-0.012 \\
(-1.683) *\end{array}$ & $\begin{array}{l}-0.012 \\
(-1.676)^{*}\end{array}$ & $\begin{array}{l}-0.012 \\
(-1.662)^{*}\end{array}$ & $\begin{array}{l}-0.011 \\
(-1.563)\end{array}$ \\
\hline Yearly fixed effect & Yes & Yes & Yes & Yes & Yes \\
\hline Adjusted $R^{2}$ & 0.197 & 0.195 & 0.194 & 0.194 & 0.198 \\
\hline
\end{tabular}

This table reports the regression of the price difference on managerial overconfidence. The dependent variable is price difference. The independent variable, MOC, and other variables are defined as in Table 2. In each cell, the regression coefficients and $z$-statistics (in parentheses) are in upper and lower case, respectively. $* * *, * *$, and $*$ denote significance at the $1 \%, 5 \%$, and $10 \%$ levels, respectively.

also positively and significantly correlated with the price difference. These findings mean that the higher the debt ratio, the more eager the firm is to engage in share repurchase programs. They imply that excessive leveraging could be another manifestation of overconfidence, in the sense that managers are reluctant to issue undervalued equity (leading to a high debt ratio) or they are confident enough in their firm's value to issue more debt to finance the repurchases. Extreme overconfidence is therefore associated with a significant price rebound. Finally, takeover threat is positively correlated with the price difference. This result could be attributable to outside investors interpreting the share repurchase program as more aimed at entrenching the managers than signaling undervaluation. 
Table 9 Announcement returns and managerial overconfidence

\begin{tabular}{lcllll}
\hline & CAR $(-1,1)$ & CAR $(-5,5)$ & CAR $(0,20)$ & CAR $(0,40)$ & CAR $(0,60)$ \\
& $(N=1937)$ & $(N=1937)$ & $(N=1937)$ & $(N=1937)$ & $(N=1937)$ \\
\hline Intercept & 6.039 & 8.489 & 13.920 & 13.753 & 0.419 \\
MOC4 & $(2.700)^{* * *}$ & $(2.205)^{* *}$ & $(2.806)^{* * *}$ & $(1.877)^{*}$ & $(0.043)$ \\
& 0.350 & 0.563 & -1.313 & -4.460 & -5.155 \\
Ln (No.) & $(0.712)$ & $(0.665)$ & $(-1.204)$ & $(-2.769)^{* * *}$ & $(-2.422)^{* *}$ \\
& -0.796 & -1.321 & -0.257 & -1.074 & -1.147 \\
Size & $(-3.894)^{* * *}$ & $(-3.756)^{* * *}$ & $(-0.567)$ & $(-1.604)$ & $(-1.296)$ \\
BM & -0.286 & -0.619 & -0.703 & -0.641 & 0.033 \\
& $(-2.249)^{* *}$ & $(-2.828)^{* * *}$ & $(-2.491)^{* *}$ & $(-1.537)$ & $(0.060)$ \\
ROE & 0.822 & 2.440 & 2.263 & 4.123 & 5.639 \\
& $(2.104)^{* *}$ & $(3.629)^{* * *}$ & $(2.613)^{* * *}$ & $(3.222)^{* * *}$ & $(3.335)^{* * *}$ \\
FCF & -0.012 & -0.050 & -0.081 & -0.079 & -0.117 \\
& $(-0.644)$ & $(-1.573)$ & $(-1.989)^{* *}$ & $(-1.323)$ & $(-1.470)$ \\
Cash & 2.027 & 9.991 & 4.338 & 24.643 & 35.963 \\
& $(0.753)$ & $(2.155)^{* *}$ & $(0.726)$ & $(2.793)^{* * *}$ & $(3.084)^{* * *}$ \\
Debt & 0.929 & 5.738 & 4.145 & 9.899 & 15.959 \\
& $(0.695)$ & $(2.494)^{* *}$ & $(1.398)$ & $(2.260)^{* *}$ & $(2.758)^{* * *}$ \\
Stock options & -0.038 & -0.065 & -0.034 & -0.059 & -0.063 \\
& $(-2.816)^{* * *}$ & $(-2.770)^{* * *}$ & $(-1.146)$ & $(-1.320)$ & $(-1.078)$ \\
INVO & -5.770 & -5.656 & -0.158 & -11.490 & -18.908 \\
& $(-1.411)$ & $(-0.804)$ & $(-0.017)$ & $(-0.858)$ & $(-1.068)$ \\
D (takeover) & -0.343 & -1.510 & -0.700 & -2.674 & -2.675 \\
& $(-1.126)$ & $(-2.878)^{* * *}$ & $(-1.035)$ & $(-2.678)^{* * *}$ & $(-2.028)^{* *}$ \\
CGI & -2.851 & -3.767 & -5.364 & -5.110 & -7.482 \\
& $(-2.924)^{* * *}$ & $(-2.245)^{* *}$ & $(-2.481)^{* *}$ & $(-1.600)$ & $(-1.773)^{*}$ \\
Dividend payout & -0.057 & 0.083 & 0.234 & 0.495 & 0.736 \\
Adjusted $R^{2}$ & $(-0.699)$ & $(0.590)$ & $(1.284)$ & $(1.839)^{*}$ & $(2.068)^{* *}$ \\
\hline & 0.062 & 0.094 & 0.211 & 0.434 & 0.449 \\
& $(0.810)$ & $(0.714)$ & $(1.242)$ & $(1.726)^{*}$ & $(1.350)$ \\
& 0.024 & 0.052 & 0.027 & 0.043 & 0.037 \\
\hline
\end{tabular}

This table reports the regressions of the abnormal returns following repurchase announcements in the different windows (CAR) on managerial overconfidence (MOC) and other control variables. These variables are defined as in Table 2 . In each cell, the regression coefficients and $z$-statistics (in parentheses) are in upper and lower case, respectively. $* * *, * *$, and * denote significance at the $1 \%, 5 \%$, and $10 \%$ levels, respectively.

Table 9 presents additional results relating MOC to the number of share repurchase programs per firm, in this case defined in terms of the announcement returns in different windows. The regression analysis reveals that MOC is significantly and negatively correlated with $\operatorname{CAR}(0,40)$ and $\operatorname{CAR}(0,60)$. However, the relations between MOC and the short-event windows, namely, $\operatorname{CAR}(-1,1), \operatorname{CAR}(-5,5)$, and $\operatorname{CAR}(0,20)$, are not significant. These results imply that the market is relatively unaffected by share repurchase announcements made by overconfident managers. As the deadline for program execution approaches, the market is increasingly able to discern MOC, causing it to attach lower valuations to share repurchase programs launched by overconfident 
managers. Moreover, we find that the number of programs per firm is negatively correlated with CAR $(-1,1)$ and CAR $(-5,5)$. A possible explanation of this result is that managers intermittently issue promising news (e.g., about how well their share repurchases are going) to increase the share price. However, this marginal positive effect decreases as the number of signals accumulates.

As for the other control variables, book-to-market equity is positively and significantly correlated with the value of the announcement returns. This result is consistent with the undervaluation hypothesis, according to which small and high book-to-market firms tend to be undervalued and therefore yield relatively high announcement returns. Moreover, free cash flow is positively and significantly correlated with CAR $(-5,5)$, CAR $(0,40)$, and CAR $(0,60)$, as is cash level with CAR. These results are consistent with the excess capital hypothesis of Easterbrook (1984) and Jensen (1986), implying that repurchasing stock is a flexible way to distribute excess cash and to solve the agency problem of excessive cash.

We find that investment opportunity is negatively and significantly correlated with the announcement returns. This result can be explained by the undervaluation hypothesis because firms with high growth potential are relatively unlikely to be undervalued; their share repurchase programs tend to be associated with low valuation. From a different perspective, the market assumes that these high-growth firms should have better investment opportunities than a share repurchase program, and therefore, they attach a low appraisal value to share repurchase programs launched by high-growth firms. Finally, takeover threat is negatively associated with the the returns, implying that share repurchase programs aimed at entrenching management are not welcomed by the market.

\section{ROBUSTNESS CHECK}

In the previous sections, we treat MOC as an exogenous variable. However, if MOC is acquired and affected by the characteristics of other firms, our conclusion that MOC drives the impulse to execute many large share repurchase programs might not be sustainable. To check for robustness, we thus perform a two-stage regression, using the first stage to isolate the residual MOC that is unrelated to another firm's characteristics. This first regression model is as follows:

$$
M O C_{i, t}=\beta_{0}+\beta_{1} S I Z E_{i, t}+\beta_{2} R O E_{i, t}+\beta_{3} B M_{i, t}+\beta_{4} F C F_{i, t}+\varepsilon_{i} .
$$

The residual from this model is then included in the second-stage regression:

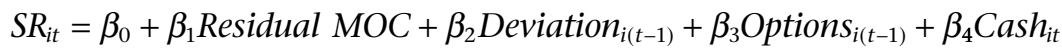

$$
\begin{aligned}
& +\beta_{5} I_{N V O}+\beta_{6} \text { Takeover }_{i(t-1)}+\beta_{7} \text { Payout }_{i(t-1)}+\beta_{8} C G I_{i t}+\varepsilon_{i t}
\end{aligned}
$$

The results summarized in Table 10 are qualitatively similar to the previous findings. A noteworthy point is that corporate governance is now positively and 
Table 10 Exogenous overconfidence and shares repurchased

\begin{tabular}{lccccc}
\hline & $\begin{array}{c}\text { \% Shares rep. } \\
(N=2003)\end{array}$ & $\begin{array}{c}\text { \% Dol. rep. } \\
(N=2003)\end{array}$ & $\begin{array}{c}\text { \% Execution } \\
(N=2003)\end{array}$ & $\begin{array}{c}\text { Ln (times) } \\
(N=2004)\end{array}$ & $\begin{array}{c}\text { PD } \\
(N=1642)\end{array}$ \\
\hline Intercept & 1.531 & 1.012 & 71.297 & 2.048 & 0.383 \\
& $(8.772)^{* * *}$ & $(6.146)^{* * *}$ & $(19.297)^{* * *}$ & $(20.314)^{* * * *}$ & $(10.662)^{* * *}$ \\
Residual (MOC) & 0.233 & 0.320 & 5.868 & 0.080 & 0.051 \\
& $(1.989)^{* *}$ & $(2.904)^{* * *}$ & $(2.369)^{* *}$ & $(1.194)$ & $(2.080)^{* *}$ \\
Cash & 1.463 & 1.016 & -0.320 & -0.393 & -0.104 \\
& $(4.700)^{* * *}$ & $(3.460)^{* * *}$ & $(-0.049)$ & $(-2.226)^{* *}$ & $(-1.597)$ \\
Debt deviation & 0.009 & 0.004 & 0.029 & -0.012 & 0.002 \\
& $(2.907)^{* * *}$ & $(1.432)$ & $(0.444)$ & $(-7.139)^{* * *}$ & $(3.090)^{* * *}$ \\
Stock options & 0.244 & 0.070 & 35.590 & -0.562 & 0.180 \\
& $(0.247)$ & $(0.075)$ & $(1.703)^{*}$ & $(-0.981)$ & $(0.929)$ \\
INVO & -0.255 & -0.353 & -2.772 & -0.329 & 0.031 \\
& $(-4.736)^{* * *}$ & $(-6.954)^{* * *}$ & $(-2.432)^{* *}$ & $(-9.767)^{* * * *}$ & $(2.747)^{* * *}$ \\
D (takeover) & -0.044 & 0.128 & -12.975 & -0.311 & 0.094 \\
& $(-0.192)$ & $(0.595)$ & $(-2.693)^{* * *}$ & $(-2.395)^{* *}$ & $(1.989)^{*}$ \\
CGI & 0.076 & 0.084 & -0.248 & -0.047 & -0.003 \\
& $(3.390)^{* * *}$ & $(3.933)^{* * *}$ & $(-0.519)$ & $(-3.701)^{* * * *}$ & $(-0.668)$ \\
Dividend payout & 0.007 & 0.010 & 0.647 & 0.005 & -0.011 \\
& $(0.406)$ & $(0.581)$ & $(1.672)^{*}$ & $(0.499)$ & $(-1.648)^{*}$ \\
Yearly fixed effect & Yes & Yes & Yes & Yes & Yes \\
Adjusted $R^{2}$ & 0.021 & 0.063 & 0.017 & 0.215 & 0.198 \\
\hline
\end{tabular}

This table reports the tobit regression of the variables of interest (percentage of shares repurchased, repurchase dollar percentage, execution percentage, the natural logarithm of the number of repurchases, and price difference) on exogenous overconfidence, defined as the residual term of the following regression: $M O C_{i, t}=\beta_{0}+\beta_{1} S I Z E_{i, t}+\beta_{2} R O E_{i, t}+\beta_{3} B M_{i, t}+\beta_{4} F C F_{i, t}+\varepsilon_{i,}$, as defined in Table 2. In each cell, the regression coefficients and $t$-statistics (in parentheses) are reported in upper and lower case, respectively. $* * *, * *$, and * denote significance at the 1\%, 5\%, and $10 \%$ levels, respectively.

significantly correlated with the average size of the repurchase programs and negatively and significantly correlated with the number of such programs per firm. From an alternative perspective, corporate governance might play a positive role in affecting share repurchase programs, assuming that the variance shared by MOC and the corporate governance index is isolated. It is firms with a good governance structure that tend to launch large repurchase programs. However, such programs also have execution costs that deter firms with good governance structures from repeatedly launching repurchase programs.

Someone might argue that the share repurchase programs executed during the financial turmoil caused by the 2008 financial crisis might be more a rational strategy to maintain the price level of the shares than an irrational strategy resulting from MOC. Thus, we rerun all the tables excluding the data from 2008. These (unreported) results are qualitatively similar to those from the full sample. Our interpretation relating MOC to share repurchasing therefore remains intact.

The data on the scale of the repurchase programs and the proportion of them that were executed support the hypothesized positive relation between MOC 


\title{
International Review of Finance
}

and the intensity of share repurchase programs. The only exception is the number of programs per firm. To address this anomalous result, we conducted another robustness check, this time recounting the number of repurchase programs per firm that occur after a managerial changeover. In so doing, the independent variable (MOC) and the dependent variable (number of repurchases per firm) were indebted to the managers. However, the result is still not significant.

The results involving debt deviation obviously contradict the optimal leverage hypothesis. To ensure that our finding is valid, we rescale the debt deviation variable by converting it to a dummy, coded 1 if the observed debt ratio is below the optimal debt ratio, and 0 otherwise. The purpose of the analysis is to see whether firms with debt below the optimal level adjusted their capital structure differently than did the firms that are above the optimal level. If the optimal leverage hypothesis is correct for our data, we would expect to find the regression coefficient to be significantly positive. However, the regression coefficient is significantly negative. Therefore, our results do not support the optimal leverage hypothesis.

\section{CONCLUDING REMARKS}

In this paper, we examine how the level of MOC affects the intensity of share repurchase programs launched by overconfident managers with respect to their scale, execution, number, and market response. We find the level of MOC to be positively correlated with the intensity of the programs. In general, we find that the market appraised MOC negatively, at least partly because firms with overconfident managers are relatively likely to be undervalued. Firms that launch intensified share repurchase programs are appraised positively; it takes 2 to 3 months for the negative appraisal to set in.

Our paper contributes to the growing literature on behavioral corporate finance. Previous studies in this area have examined the relation between the behavioral characteristics of corporate managers and corporate policies (e.g., Malmendier and Tate 2005a, 2008; Baker et al. 2007; Ben-David et al. 2007; Hackbarth 2008; Malmendier et al. 2010). Our results indicate that MOC indeed affects the intensity of share repurchase programs. However, sophisticated investors are not taken in by the impulses of overconfident managers to launch large and intensive share repurchase programs that cannot be justified.

\author{
Pei-Gi Shu \\ Department of Business Administration \\ $\mathrm{Fu}$ Jen Catholic University \\ 510 Jhongjheng Rd. \\ Sinjhuang, New Taipei City, 24205 \\ Taiwan \\ 036047@mail.fju.edu.tw
}




\section{Managerial Overconfidence and Share Repurchase}

\section{REFERENCES}

Alicke, M., M. Klotz, D. Breitenbecher, and T. Yurak (1995), 'Personal Contact, Individuation, and the Better-Than-Average Effect', Journal of Personality \& Social Psychology, 68, 804-25.

Alicke, M. D. et al. (1985), 'Global Self-Evaluation as Determined by the Desirability and Controllability of Trait Adjectives', Journal of Personality and Social Psychology, $49,1621-30$.

Asquith, P., and D. Mullins (1986), 'Signalling with Dividends, Stock Repurchases, and Equity Issues', Financial Management, 15, 27-44.

Bagwell, L. S. (1991), 'Share Repurchase and Takeover Deterrence', Rand Journal of Economics, 22, 72-88.

Bagwell, L. S., and J. B. Shoven (1989), 'Cash Distribution to Shareholders', Journal of Economic Perspectives, 3, 129-40.

Baker, M., R. S. Ruback, and J. Wurgler (2007), 'Behavioral Corporate Finance: A Survey', Handbook of Corporate Finance: Empirical Corporate Finance (Vol. 1).

Ben-David, I., J. R. Graham, and C. R. Harvey (2007), 'Managerial Overconfidence and Corporate Policies', NBER Working Paper, No. W13711.

Boehren, O., and B. Oedegaard (2003), 'Governance and Performance Revisited', Working Paper, No. 28.: European Corporate Governance Institute.

Brown, R., and N. Sarma (2007), 'CEO Overconfidence, CEO Dominance and Corporate Acquisition', Journal of Economics and Business, 59, 358-79.

Buffett, W. E. (2012), 'Warren Buffett's Letters to Berkshire Shareholders', BERKSHIRE HATHAWAY INC. Available at http://www.berkshirehathaway.com/letters/2011ltr. pdf.

Camerer, C., and D. Lovallo (1999), 'Overconfidence and Excess Entry: An Experimental Approach', American Economic Review, 89, 306-18.

Comment, R., and G. A. Jarrell (1991), 'The Relative Signaling Power of Dutch-Auction and Fixed-Price Self-Tender Offers and Open-Market Share Repurchases', Journal of Finance, 46, 1243-71.

Cooper, A. C., C. Y. Woo, and W. C. Dunkelberg (1988), 'Entrepreneurs' Perceived Chances for Success', Journal of Business Venturing, 3, 97-109.

Dann, L. (1981), 'Common Stock Repurchases: An Analysis of Returns to Stockholders and Bondholders', Journal of Financial Economics, 9, 113-38.

Dann, L. Y., R. W. Masulis, and D. Mayers (1991), 'Repurchase Tender Offers and Earnings Information', Journal of Accounting and Economics, 14, 217-51.

Deshmukh, S., A. M. Goel, and K. M. Howe (2010), 'CEO Overconfidence and Dividend Policy', Working Paper, DePaul University.

Dittmar, A. K. (2000), 'Why Do Firms Repurchase Stock?', Journal of Business, 73, 331-55.

Dunsby, A. (1994), 'Share Repurchases, Dividends, and Corporate Distribution Policy', Working Paper. Philadelphia: University of Pennsylvania.

Easterbrook, F. H. (1984), 'Two Agency Cost Explanations of Dividends', American Economic Review, 74, 650-59.

Feather, N. T., and J. G. Simon (1971), 'Attribution of Responsibility and Valence of Outcome in Relation to Initial Confidence and Success and Failure of Self and Other', Journal of Personality and Social Psychology, 18, 173-88.

Fenn, G. W., and N. Liang (1997), 'Good News and Bad News about Share Repurchases', Working Paper. Washington, DC: Board of Governors of the Federal Reserve.

Gervais, S., J. B. Heaton, and T. Odean (2003), 'Overconfidence, Investment Policy, and Executive Stock Options', Working Paper, Duke University.

Goel, A. M., and A. V. Thakor (2008), 'Overconfidence, CEO Selection, and Corporate Governance', Journal of Finance, 63, 2737-84. 


\section{International Review of Finance}

Grullon, G., and R. Michaely (2002), 'Dividends, Share Repurchases, and the Substitution Hypothesis', Journal of Finance, 57, 1649-84.

Hackbarth, D. (2008), 'Managerial Traits and Capital Structure Decisions', Journal of Financial and Quantitative Analysis, 43, 843-81.

Heaton, J. B. (2002), 'Managerial Optimism and Corporate Finance', Financial Management, 31, 33-45.

Hertzel, M., and P. C. Jain (1991), 'Earnings and Risk Changes around Stock Repurchase Tender Offers', Journal of Accounting and Economics, 14, 253-74.

Hovakimain, A., G. Hovakimain, and H. Tehranian (2004), 'Determinants of Target Capital Structure: The Case of Dual Debt and Equity Issues', Journal of Financial Economics, 71, 517-40.

Hribar, P., and H. Yang (2010), 'Does CEO Overconfidence Affect Management Forecasting and Subsequent Earnings Management?', Working Paper, University of Iowa.

Ikenberry, D., J. Lakonishok, and T. Vermaelen (1995), 'Market Underreaction to Open Market Share Repurchases', Journal of Financial Economics, 39, 181-208.

Jensen, M. C. (1986), 'Agency Costs of Free Cash, Corporate Finance, and Takeovers', American Economic Review, 76, 323-29.

Jolls, C. (1996), 'The Role of Compensation in Explaining the Stock-Repurchase Puzzle', Working Paper. Cambridge, MA: Harvard Law School.

Kruger, J. (1999), 'Lake Wobegon Be Gone! The Below-Average Effect and the Egocentric Nature of Comparative Ability Judgments', Journal of Personality and Social Psychology, 77, 221-32.

Landier, A., and D. Thesmar (2009), 'Financial Contracting with Optimistic Entrepreneurs', The Review of Financial Studies, 22, 117-50.

Langer, E. J. (1975), 'The Illusion of Control', Journal of Personality and Social Psychology, 32, 311-28.

Larwood, L., and W. Whittaker (1977), 'Managerial Myopia: Self-Serving Biases in Organizational Planning', Journal of Applied Psychology, 62, 194-98.

Lee, D. S., W. H. Mikkelson, and M. M. Partch (1992), 'Managers' Trading around Stock Repurchases', Journal of Finance, 37, 1947-61.

Malmendier, U., and G. Tate (2005a), 'CEO Overconfidence and Corporate Investment', Journal of Finance, 60, 2661-700.

Malmendier, U., and G. Tate (2005b), 'Does Overconfidence Affect Corporate Investment? CEO Overconfidence Measures Revised', European Financial Management, 11, 649-59.

Malmendier, U., and G. Tate (2008), 'Who Makes Acquisitions? CEO Overconfidence and the Market's Reaction', Journal of Financial Economics, 89, 20-43.

Malmendier, U., G. Tate, and J. Yan (2010), 'Managerial Beliefs and Corporate Financial Policies', NBER Working Paper, No. 15659.

Miller, D. T., and M. Ross (1975), 'Self-Serving Bias in Attribution of Causality: Fact or Fiction?', Psychological Bulletin, 82, 213-25.

Moore, D. A., and T. G. Kim (2003), 'Myopic Social Prediction and the Solo Comparison Effect', Journal of Personality and Social Psychology, 85, 1121-35.

Nisbett, R. E., and L. R. Ross (1980), Human Inference: Strategies and Shortcomings of Social Judgment. Englewood Cliffs, NJ: Prentice-Hall.

Opler, T., and S. Titman (1996), 'The Debt-Equity Choice: An Analysis of Issuing Firms', Working Paper. Columbus: Ohio State University.

Purnanandam, A. K., and B. Swaminathan (2004), 'Are Ipos Really Underpriced?', Review of Financial Studies, 17, 811-45.

Rhodes-Kroph, M., D. T. Robinson, and S. Viswanathan (2005), 'Valuation Waves and Merger Activity: the Empirical Evidence', Journal of Financial Economic, 77, 561-603. 
Roll, R. (1986), 'The Hubris Hypothesis of Corporate Takeovers', Journal of Business, 59, 197-216.

Schrand, C., and S. L. C. Zechman (2012), 'Executive Overconfidence and the Slippery Slope to Financial Misreporting', Journal of Accounting and Economics, 53, 311-29.

Stephens, C. P., and M. S. Weisbach (1998), 'Actual Share Reacquisitions in Open-Market Repurchase Programs', Journal of Finance, 53, 313-34.

Svenson, O. (1981), 'Are We All Less Risky and More Skillful Than Our Fellow Drivers?', Acta Psychologica, 47, 143-48.

Vermaelen, T. (1981), 'Common Stock Repurchases and Market Signaling: An Empirical Study', Journal of Financial Economics, 9, 139-83.

Weinstein, N. (1980), 'Unrealistic Optimism about Future Life Events', Journal of Personality and Social Psychology, 39, 806-20.

Yu, Y. M. (2011), 'Two Essays on Open Market Share Repurchases', Available at http:// ndltd.ncl.edu.tw/cgi-bin/gs32/gsweb.cgi?o=dnclcdr\&s=id=\%22099NCU 05304002\%22.\&searchmode=basic. 